\title{
Analysis of Marketing Strategy of Rural E-commerce Platform under O2O Business Mode - Case Study of "Cuncunle"
}

\author{
DuFan \\ School of Business \\ NENU \\ 961292826@qq.com
}

\author{
Cheng-Yue Yin \\ School of Business \\ NENU \\ Yincy653@nenu.edu.cn
}

\begin{abstract}
The government proposed the development mode of "Internet+" in 2015, which drives the prosperity of internetrelated market in China. Rural market also becomes a "sweet pastry" of e-commerce enterprises in such a wave. In order to accelerate the expansion of rural e-commerce business, numerous famous e-commerce enterprises such as Jingdong and Alibaba enter the rural market one after another. However, rural market has many features which are difficult to change. For example, backward consumption concept brings big difficulties for the development rural e-commerce. Therefore, e-commerce enterprises should further discuss marketing strategy when exploiting rural market. In this paper, features of rural market and $\mathrm{O2O}$ business mode are concluded through literature review. Besides, the opportunities and challenges faced by e-commerce enterprises during the development of rural market are also concluded. Meanwhile, O2O rural layout mode of "Cuncunle" Enterprise which was selected twice as course case of Harvard Business School is analyzed, and comparative analysis of advantages and disadvantages of the marketing strategy used by "Cuncunle" Enterprise is conducted. Finally, the marketing strategy suitable for enterprises to open up rural market is sorted out.
\end{abstract}

Keywords-O2O; Rural market; E-commerce; Marketing strategy

\section{INTRODUCTION}

In the development tide of "Internet+", the rural market with huge market potential welcomes the good development opportunity because of strong policy support and promotion of mobile intelligent popularization rate, and becomes a new field that numerous e-commerce enterprises contend for. According to 2016 Report on Chinese Network Retail Market Data Monitoring, the market scale of rural online shopping in China reached RMB 353 billion in 2015, while this figure was RMB 482.3 billion in 2016 , up $36.6 \%$ year on year. It is predicted that, the figure will break through RMB 600 billion in 2017. The future consumption scale may exceed cities. The State Council issued Opinions on Strong Development of Ecommerce and Acceleration of new Economic Power Cultivation to stress active development of rural e-commerce and encourage agricultural production means enterprises to develop e-commerce. However, the inherent shortcomings of rural area such as a vast land with a sparse population and too high logistics cost largely restrict the development of rural ecommerce. Hence, based on analyzing predecessors' researches and case enterprise selected in "Business at the Base of the Pyramid Class" at Harvard University, this paper summarizes e-commerce mode of the case enterprise. On the one hand, this paper finds out the effective breakthrough points for the development of numerous rural e-commerce enterprises and provides reference for the enterprises which apply e-commerce platforms to open up the rural market. On the other hand, this paper explores the theory of user experience improvement with $\mathrm{O} 2 \mathrm{O}$ mode and offers reference for people to research rural ecommerce.

\section{O2O Business MODE AND RURAL E-COMMERCE}

\section{A. Concept of $\mathrm{O} 2 \mathrm{O}$ business mode}

About the definition of $\mathrm{O} 2 \mathrm{O}$ business mode, theoretical circle and practical circle fail to form the united cognition. Through summing up predecessors' researches, we decide to use the widely accepted concept: $\mathrm{O} 2 \mathrm{O}$ (Online To Offline) is to combine offline business opportunities with internet to make internet become the medium of offline transaction [1]. Through the offline service and online customer attraction, consumers screen services online and trade online. The most obvious feature of this mode is that, the promotion effect can be checked, and each transaction can be tracked. A core advantage of $\mathrm{O} 2 \mathrm{O}$ is that it breaks through the space limit of customer's consumption, and solves the problem of insufficient ecommerce experience. Existing business forms of $\mathrm{O} 2 \mathrm{O}$ can be classified into three types: Online to Offline (online transaction to offline experience), such as meituan.com; Offline to Online (offline marketing to online transaction), such as YHD.com; Offline to Online to Offline (offline marketing to online transaction to offline consumption experience), such as the marketing campaign of China mobile Fuzhou Branch "look for yourself". 


\section{B. Rural e-commerce}

Rural e-commerce is a product of e-commerce rise in rural area. Rural e-commerce refers to coverage of rural production, sale and supply links through network platform and supply of full-process e-commerce service for rural area including information, transaction, settlement and transportation[2][3]. Thus, rural e-commerce can be simplified as the process of ecommerce orientation of rural market. Rural e-commerce services include online farmer's market, digital agritainment, characteristic tourism, characteristic economy and investment promotion, etc [4]. According to the different modes, rural ecommerce modes can be classified into three types: Suichang Mode of platform way, Chengxian Mode of resources integration way, and Tongyu Mode of branding way [5]. Li Xingkai considers rural e-commerce modes can be classified into four types: the first mode is from top to bottom [6]. The government takes the lead to develop and utilize the authority and resources of the government to establish the information platform. The second mode is from bottom to top. According to farmers' requirements, they spontaneously organize to form industrial cluster alliance to help joint development of them and partners. The third mode is under the help of famous ecommerce platform. In other words, groups and individuals set up shops on Taobao, Jingdong and other e-commerce websites. The final mode is to establish e-commerce platforms. This method is applicable to those agricultural products enterprises with certain strength and independent construction need.

In the development process of rural e-commerce, opportunities and challenges coexist due to its own features. Opportunities are mainly reflected in five aspects. Firstly, rural e-commerce market is wide, rural e-commerce market owns population base advantage. Secondly, rural e-commerce consumption belongs to the initial stage, and the power of consumption becomes stronger and stronger. Thirdly, rural ecommerce development is imbalanced. Fourthly, entrepreneurs of rural e-commerce are usually young, with vitality. Fifthly, rural e-commerce development has the possibility of industry reengineering. Of course, challenges cannot be ignored. It is hard to overcome rural traditional transaction modes and habits. The rural area is sparsely populated, and the logistics cost is too high. There are short of relevant talents, and rural labor force is seriously imbalanced.

\section{CASE ANALYSIS}

\section{A. Introduction of Cuncunle}

Cuncunle (Http://www.cuncunle.com) is an internet entrepreneurship service platform, rural integrated marketing communication platform, rural agricultural material circulation platform and rural financial service platform serving for the rural area in China. Since it was set up in 2009, it has been devoted to making "new rural internet platform based on acquaintance society", enhancing urban and rural connection and serving for the rural area. Its founder was invited twice by Harvard Business School in 2016 and 2017 to share its business cases. The founder of Cuncunle $\mathrm{Hu}$ Wei originally wanted to make a "villager record" with the unit of village by referring to alumni record. Many peasant-workers or college students leaving from the rural area want to know he changes of their hometowns. They often search their villages online. Cuncunle as a platform with the widest converge and the most complete information can be searched by netizens soon. In addition, some station leaders are also the village head, village secretary or college graduate village official. They want to find out a platform to release the information. The platform exactly meets such demand. The amount of information updated every day is very huge, with both pictures and texts. Besides, the information is true. Therefore, the platform scale continues to expand. On this basis, Cuncunle also becomes the largest person search platform in China. True person search information will be issued on the platform every day. Many find out their primary school classmates or comrade-in-arms via Cuncunle. Even some veterans from Taiwan entrust attorneys to search persons on Cuncunle.

As the amount of information on the website continues to increase, Cuncunle starts to introduce many resources and funds to assist the station leaders in becoming rich, such as introducing more strategic cooperation, selling seeds and chemical fertilizers, becoming brokers of agricultural products, and helping them sell agricultural products. Even, Cuncunle will introduce some funds to invest in the rural area, look for some willing to work in the rural area, give them fund support and system support as well as direction guidance so as to help them start up business. Besides, Cuncunle will continuously introduce new projects and expand the business scope in the later period. Hence, it becomes the leader of rural e-commerce enterprises.

\section{B. Operation of "Cuncunle"}

Cuncunle has been rapidly accepted by people in recent years, which cannot be separated from localized $\mathrm{O} 2 \mathrm{O}$ business operation mode. Its operation mode expands from online and offline aspects.

Online recruitment of network village officials: SEO strategy is directly integrated in website framework design. When you search the names of some villages on each search engine, Cuncunle will appear soon. This guarantees basic traffic flow. After a user logs in the website, if nobody serves as the network village official of this village, he may register and apply. Besides, he may serve as the administrator of the village website. The administrator has two advantages. The first one is face. He like forum moderator can manage a module. It is a great honor. Meanwhile, he will invite many villagers to $\log$ in then theme website of the village. The second one is money making. He may undertake part-time earning chance to do some offline things to make money. Over the past years, Cuncunle has recruited more than 200000 network village officials which also become one of the most valuable resource of Cuncunle.

Offline rural market promotion; since almost all village officials are the village secretary and college graduate village official who have human resources and prestige in villages, Cuncunle owns rural market promotion channel. By utilizing the opportunity of the policy "home appliance going to rural area", the business has developed rapidly, and certain scale has formed. These business are very down-to-earth and common, and pure internet companies cannot do these business, such as 
wall advertising: at least three walls in each village, and at least three months for each cycle; itinerant exhibition of road show: specified or recommended region, at least one week for one cycle; films going to the rural area: June-October every year, at least three months for one cycle; village committee broadcast: the fixed time bucket every day or every week, at least one month for one cycle; countryside store promotion: at least one for each village, at least one year for one cycle. The cost of TV advertising and new media advertising increases continuously, and false information is seen everywhere. Besides, these are subjectively shielded more and more easily. The propaganda effect of advertisements drops increasingly. In the simple villages, these propaganda channels close to people's life will be more and more easily valued by entrepreneurs.

\section{Contrastive analysis of "Cuncunle"}

\section{Contrastive analysis of Jingdong, Taobao and Cuncunle}

The whole planning of the tycoon Alibaba is divided into three stages. The first stage is "the plan of 1000 countries and 10000 villages". The second stage is to start rural Taobao 2.0 mode, the third stage is to implement four strategies: rural Taobao partner strategy, rural logistics development strategy, rural financial support strategy, and rural e-commerce talent training strategy. Jingdong adopts " $3 \mathrm{~F}$ strategy" of rural ecommerce, i.e. Factory to Country, Finance to Country, and Farm to Table. By contrast, both Jingdong and Taobao take the way of "surrounding the countryside with cities". The convenience which can be really brought to farmers is limited. For example, farmers want sell out the fruits and vegetables on the markets in their village and adjacent villages. "Cuncunle" takes the way of $\mathrm{O} 2 \mathrm{O}$ platform, i.e. "surrounding cities with the countryside". In essence, Cuncunle is a comprehensive web portal oriented to the rural area. It integrates numerous elements such as information, social contact and e-commerce. In the form, such presentation form is not innovative. Compared with all rural $\mathrm{O} 2 \mathrm{O}$, the pioneering work of Cuncunle is to establish the concepts of village community and "network village official". The network community makes the connection among villages become closer and brings more convenience for villagers. Meanwhile, by utilizing management power and actual operation benefit, Cuncunle gathers over 100000 village managers and college students and makes them become the terminal of product promotion. This solves the problem of brand recognition. Moreover, network managers spare no effort to drive offline villages to activate through numerous communities.

Contrastive analysis of TTQ (www.ttq.com), YNC (www.ync365.com) and Cuncunle

The full name of TTQ is Shenzhen Tiantian Circle Agricultural Service Co., Ltd.. It is an O2O service platform which integrates Agricultural materials manufacturers in the upstream and dealers in the midstream, provides consumer entrance in the downstream and develops professional plantation knowledge and agricultural finance. YNC, set up byBeijing Tianchen Cloud Farm Co., Ltd. in February 2014, is an online agricultural material transaction platform. It mainly provides farmers with seeds, pesticides, chemical fertilizers, agricultural machinery transactions as well as land measurement, fertilizer matching and agricultural technical services.

By contrast, Cuncunle has the following differences. Firstly, the platform nature is different. TTQ integrates the marketing channels and allies manufacturers, dealers and retail stores so as to direct connect with farmers. It is a simple $\mathrm{O} 2 \mathrm{O}$ service platform which reduces the channel cost and achieves win-win of three parties. YNC is a third-party shopping platform. Merchants and retail investors enter the platform, and the service station and individual users directly order. Cuncunle is a web portal oriented to the rural area in China. It is a comprehensive internet communication platform which organically combines network-based social contact, classified information and e-commerce. Secondly, target customers are different. TTQ and YNC sell agricultural materials, bring convenience for farmers and help them save money. But, the customers of Cuncunle not just contain farmers, but also include merchants and enterprises. It not just helps farmers save money, but also helps merchants and enterprises save money. In particular, I helps villagers make money. Thirdly, the management mode is different. Original enterprises of TTQ and YNC manage the platform, and merchants manage their community pages. However, Cuncunle adopts the management mode of "breaking up the whole into parts". In other words, the whole rural area is divided into each station, and the station leader is arranged for management. It first recruited more than 200000 network village officials and then utilized the force to promote the rural market offline.Some Common Mistakes

\section{Marketing strategy analysis of "Cuncunle"}

\section{Advantages of current marketing strategy}

(1) Target market selection: As most company choose towns as their target market. But Cuncunle chose the rural area as the target 6 years ago and gradually developed by taking establishment of rural "alumni records" as the starting point.

(2) Proper orientation: From both the functions of Cuncunle's online platform and various offline services of station leaders, we can find that it is a web portal oriented to the rural area in the whole country. It is a comprehensive internet communication platform which organically combines network-based social contact, classified information and ecommerce. Cuncunle has a high reliability in the mind of people, which has a very important promotion role for later business development and also accumulates much public trust for its development of Cuncunle supermarket and finance.

(3) Combination of relationship marketing and emotional marketing: Cuncunle perceived emotional appeal of these people early and provided corresponding needs to make it expand. Moreover, Cuncunle does not employ employees, but attract villagers to serve as the station leader. Besides, the transformed shops are used for propaganda. So, the human resources in the villages may be utilized.

\section{Main problems and suggestions}

(1) Product strategy problem. Firstly, product categories are not complete. The products with rural characteristics are not comprehensive enough on the platform. The sources of goods are limited. Secondly, fresh products are mostly sold by bulk, 
which is adverse to the purchase of individual users. Thirdly, although the platform offers ask-to-buy platform and shopping platform, users can only buy through pone consultation or interview. In my opinions, Cuncunle can optimize product structure and improve product quality. "Cuncunle" can make the best of "village people" to explore customers' differential needs and adopt proper product strategy to achieve its objective. Firstly, for the online product part, the platform structure may be optimized (such as setting up instant chatting software similar to Aliwangwang in Taobao webpage) to avoid the loss of customers due to too long waiting time after the information is released so as to make communications timely and effective. Secondly, information monitoring should be done well to make sure the information on the platform true and valid. "Cuncunle" can establish honesty system and cooperate with local industry and commerce department or consumers' association to check the information such as recruitment demand so as to firmly keep the reputation. For the offline products, in the aspect of agricultural material demand and service for rural users, Cuncunle can contact corresponding products and service providers to let farmers acquire cheap and fine agricultural materials conveniently.

(2) Price strategy problem. Since Cuncunle adopts the interview of "breaking up the whole into parts", more than 200000 network village officials recruited know the price and market differently. Even if e-commerce skills can be trained, and the website offers national and provincial-level average price for many agricultural products, village officials still depend on themselves to price. It is very difficult to improve their market sensitivity. Thus, this to certain degree hinders transactions of agricultural products and especially branding way of agricultural products. So "Cuncunle" can understand customers' practical needs through its big data, and carry out differential pricing for manufacturers on agricultural media and implement differential pricing. For the manufacturers whose products are closer to farmers' needs, the advertising price is lower. This not merely contributes to attracting more manufacturers and returning the advertising expenses saved for manufacturers and suppliers to farmers, but also can help the platform gain higher reputation.

(3) Channel building problem. Although network village officials help Cuncunle as an entrepreneurial company well sink the channel, the popularization rate is limited due to underdeveloped rural network, weak consumption and business awareness and backward network technology, So Cuncunle can promote channel depth and width. On the one hand, "Cuncunle" can carry out channel member training to promote channel quality. On the other hand, it is necessary to integrate the rural shops and expand the channel. Cuncunle may offer free WIFI and quality and cheap products for the shop to help it operate $\mathrm{O} 2 \mathrm{O}$. When the number of stops integrated exceeds a value, the width advantage of the channel will stand out.

(4) Promotion strategy application problem. We find that, Cuncunle does not advertise itself. So, although it owns so many members, the popularity is much lower than that of ecommerce tycoons. So as a rural $\mathrm{O} 2 \mathrm{O}$ platform, Cuncunle may carry out sales promotion from two aspects. On the one hand, it may hand out relevant discount coupons and cash coupons in activities or holidays and festivals through the network social contact and classified information platform so as to propagandize the business and attract new customers. On the other hand, Cuncunle should advertise itself properly to promote its brand asset.

\section{CONCLUSIONS}

From the case analysis of the results, it is especially important for startup rural e-commerce enterprises to own trustworthy partners in the village in order to really enter the rural area and gradually influence living and consumption habits of villagers. Meanwhile, appropriate marketing methods must be applied while manifesting the core advantages. Ecommerce enterprises can gain a firm foothold and continuously develop in the rural market only when they form good and proper orientation in the rural area, optimize their product structure and utilize all resources available to enhance their comprehensive strength and promote their reputation. Thus, rural e-commerce development mode in China is still and will be in the exploration stage for a long time, and many severe challenges are still confronted. $\mathrm{O} 2 \mathrm{O}$ will be an important exploration direction for rural e-commerce development.

\section{REFERENCES}

[1] Wenming Zhang.(2012) Analysis of O2O Business Model .Chinese Electronic Commerce, (3): 2-3.

[2] Li Junyang. (2015), Innovation Research on Rural Consumer Goods Circulation Industry in China. China Business and Market, 20(4):1-6

[3] Fang Cheng, (2014) Study on Exploitation of Rural E-commerce Market. Logistics \& Material Handling, 19(5):134-136

[4] Zhang Tanyu, Cui Xun. (2002), On Integrated Marketing Strategy of Investment Promotion intermediary organizations . International Business Research, (4):67-70.

[5] Wen Longguang, Pan Lijun.(2011), Accelerating Development of Rural Logistics System in China. Macroeconomic Management, (5):49-50.

[6] Li Xingkai. (2013), New Modes of Operation on Chain Supermarkets in Rural Areas. Journal of Northwest A\&F University(Social Science Edition), 13(4):48-54.

[7] Ling Shouxing.(2015), Research on Forming and Evolving Mechanism of E-commerce Industrial Cluster in China's Rural Area. Commercial Research, (1):104-109.

[8] Jalali A A, Okhovvat M R, Okhovvat M. (2011)A new applicable model of Iran rural e-commerce development.. Procedia Computer Science, 3:1157-1163.

[9] Wang Fatao, Yuan Chunhui. (2014), E-commerce Express Industry Chain Model and Correlation Analysis. China Business and Market, (1):92-97

[10] Liu Zhichao, Chen Yong, Yao Lizhi.(2014), Innovation of E- business Service Model in Big Data Era. Science and Technology Management Research, (1):31-34

[11] Dong Kunxiang, Hou Wenhua, Ding Huiping et al. (2016), The Development of Innovation-oriented E-business Cluster of Rural Area:an Analysis of Suichang Model and Shaji Model. Issues in Agricultural Economy, (10):60-69.

[12] Jiang Kan, Jin Xin, Huang Yuanfang.(2013), He Weiwei, Study on Construction of O2O E-commerce Business Model. E-commerce, 09:910.

[13] Li Zhigang.(2007), Conditions and Promotion Countermeasures for Supporting China's Rural E-commerce Development. Forum on Science and Technology in China, (1):123-126. 